\title{
Technology Transfer Related Concepts
}

Irina Iulia SALANȚ $\breve{A}^{1}$

Ioana Natalia BELEIU ${ }^{2}$

Alin MIHĂIL $\breve{A}^{3}$

Emil Lucian CRIȘAN

\begin{abstract}
Technology transfer is a fashionable term, a window towards improved processes, and also a huge part of business strategies meant to ensure competitive advantage, progress, and nonetheless, novelty for companies around the world. Due to its relevance and wide applicability, its associated concepts are even more important as they describe how technology transfer works and they also predict how technology transfer will evolve in the future.

The purpose of this paper is to present the concepts used in association with technology transfer and consequently to surpass the shortcomings of existing research. Concepts as technology transfer, technology learning, diffusion of innovation, entrepreneurship, knowledge transfer, marketing of research are placed in the context of technology transfer, based on a detailed literature review that we have performed.
\end{abstract}

Keywords: Technology transfer, technology learning, diffusion of innovation, entrepreneurship, knowledge transfer, marketing of research.

JEL classification: M10, M100

DOI: $10.24818 /$ RMCI.2018.4.422

\section{Introduction}

Today's society can be described using one word: change. In comparison to several decades ago, there have been a number of changes, such as the increase of countries that place particular emphasis on modern technologies and keep pace with technological evolution. Also, the number of trained specialists and researchers has grown in recent years. On the other hand, there are more and more governmental programs aimed at supporting the development of scientific research. These changes are more visible in countries that have a fast development compared to other less developed ones (Barton, 2007). Another particular aspect about the

\footnotetext{
${ }^{1}$ Irina Iulia Salanță, Babeș-Bolyai University, Email: irina.salanta@econ.ubbcluj.ro, Phone: 0040264418652

2 Ioana Natalia Beleiu, Babeș-Bolyai University, Email: ioana.beleiu@econ.ubbcluj.ro, Phone: 0040264418652

3 Alin Mihăilă, Babeș-Bolyai University, Email: alin.mihaila@econ.ubbcluj.ro, Phone: 0040264418652

${ }^{4}$ Emil Lucian Crișan, Babeș-Bolyai University, Email: emil.crisan@econ.ubbcluj.ro, Phone: 0040264418652
} 
current situation is globalization. This involves trade liberalization and building production facilities that operate for customers from other countries. The result of this situation is trade specialization and development. Firms need to face international competition, not just local ones, and sometimes they have to find their optimal position in a production structure that is already built at international level (Barton, 2007). The emergence of new technologies acts as a facilitator of globalization. At the same time, technologies are changing rapidly, shortening the life cycles of products and processes, increasing technology costs. Technology transfer from research institutions has become a strategic tool for companies and nations that search to meet the challenges of the global economy (Audretsch, 2014). The globalization phenomenon is present also in the fields of invention and innovation. Without new technologies, globalization would not be possible, as they play a role in the transfer of information, one characterized by speed and dynamism (Nam \& Barnett, 2011). Technology transfer is the key to many organizational shortcomings in the contemporary business environment.

But what is actually technology transfer? What does it refer to? Which activities does it include? Is it the same with technology learning and knowledge acquisition? Or does it resemble more to innovation and diffusion of innovation? Despite its various benefits technology transfer is often mistaken by a large number of different concepts. The most frequently encountered ones are: technology learning, innovation, diffusion of innovation, technological entrepreneurship, knowledge acquisition, entrepreneurship, technological change, organizational learning, any many more. Our objective is to fill this void and to clarify the differences and the relations technology transfer has with the concepts most frequently associated with. We especially focus on the relation between TT and innovation as this is the most often misunderstood. In order to accomplish this in the next section we first define technology transfer as described in the literature and also as we see it and then we focus on each term and analyze it thoroughly.

\section{Definitions for Technology Transfer}

Autio and Laamanen, (1995, cited in Albors*, Sweeney, \& Hidalgo, 2005) state that "technology comprises the ability to recognize technical problems, the ability to develop new concepts and tangible solutions to technical problems, the concepts and tangibles developed to solve technical problems, and the ability to exploit the concepts and tangibles in an effective way". In this standard view technology is understood as "knowledge of skills" which makes it transferrable to other entities. Technology transfer lies at the heart of the process of economic growth (B. W. Lin, 2003) as it is an active process, during which technology is carried across the border of two entities, which can be countries, companies, or even individuals (Albors*, Sweeney, \& Hidalgo, 2005).

Due to its strong interdisciplinary character, it is challenging to find a unitary and universal definition for TT. According to some authors technology consists of two primary components: 1) a physical component which comprises of 
items such as products, tooling, equipment, blueprints, techniques, and processes; and 2) the informational component which consists of know-how in management, marketing, production, quality control, reliability, skilled labor and functional areas (Kumar, Kumar, \& Persaud, 1999 in; Wahab, Rose, \& Osman, 2012).

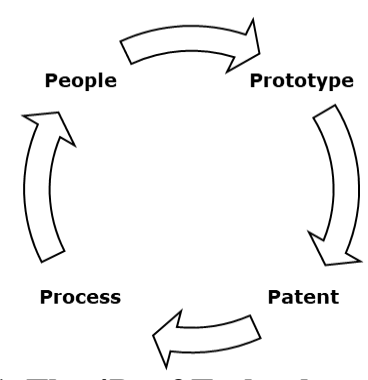

Figure 1. The 4Ps of Technology Transfer Source: (Andonova, 2015, p. 9)

The dichotomy of its components is underlined also in Figure 1, as the 4Ps of technology transfer can be grouped in hard (prototype and patent) and soft components (process and people). These four elements can easily become the structure of a set of good practice in. technology transfer, to which details will be added.

Furthermore, we consider worth examining the two words that form the central concept. For professionals which carrying out technology transfer activities, technology means more than just some sophisticated equipment or physical goods usable in the production or supply of a customer service. We define technology as the process through which an organization transforms work, capital, material resources, and information into products and services of a greater value. Technology, thus refers to the whole process of organizations that create products and services generating greater value, is considered to be a prerequisite for the sole existence of these organizations. It is useful to point out that in the quality management theory the process approach establishes that behind each product or service there are several activities that together form a process. Implicitly, it can be discussed that an organization can have more processes and also technologies, depending on the number of products/services they provide to the market. All enterprises have technologies that do not include technical, engineering or production elements, including marketing, financial, management, human resources, customer relations, logistics, etc. In this context, innovation can be defined very easily as any change made upon a certain technology, referring both to basic activities and to other activities within a process.

The second term of the construct is transfer, which does not refer strictly to moving goods from point A to point $\mathrm{B}$, but it encompasses the transference of the right of use. Le Grange and Buys (2002) explain it by using the example of a computer program which is bought, the intended functionality has not been transferred to the buyer of the program Even when the program is installed, the 
functionality has not yet been transferred. Only when the buyer uses the program, certain functionality has been transferred.

\section{Technology Transfer Related Concepts}

One of the most frequently used concept associated with technology transfer is technology knowledge about which (Winkelbach \& Walter, 2015) say it is strongly connected to the organization's absorptive capacity. Others associate technological knowledge with highly qualified workforce, with inequality in pay favoring it, and with the increase of international business (Afonso, 2013), proving once more that any economy that invests in technological knowledge gains significant advantages. In our view technological knowledge refers more to a precise set of practical skills that allow the understanding and usage of modern technologies in organizational processes which are developed due to IT increasing popularity. Technology knowledge must not be mistaken by technology transfer, as the latter is a much wider concept than the simple handling of advanced technologies.

The sources of innovation have changed drastically over the years due to the increased complexity of modern technologies which lead to the creation of technological knowledge network within organizations. Identifying these networks, expanding and constantly improving then has become managers' recent focus. All these can be achieved in two possible ways (Shin \& Park, 2010). The first one relies on cost reductions and the second one on establishing strategic objectives. These are easier said than done as there is an indirect relations between enlarging the technological knowledge network and cost reduction. Moreover finding the right, complex, but attainable, yet provocative and realistic strategic objective is not a simple task. Taking a closer look inside these networks, one could notice they are made of a complex knowledge flow, which is defined as the direct movement of knowledge between different actors involved in this process (Shin \& Park, 2010). Furthermore, the knowledge flow is a dynamic concept strongly dependent on the amount of technological transfer the organization is subjected to. Due to this particular aspect, technological knowledge networks cannot be analyzed without mentioning technology transfer, but the two should not be mistaken.

Another concept very frequently associated and mistaken with technology transfer is technological learning. Even if these two are strongly connected, there are also significant differences between them. Technological learning refers to how technology transfer is assimilated and adapted by the receiving organization, the focus is on how the new technology evolves into a strategic asset (B.-W. Lin, 2003). Organizational intelligence determines the technological learning performance and the characteristics of technological knowledge such as causal ambiguity and firm specificity (B.-W. Lin, 2003).

Technological learning interests us as it is a process that starts in the donor organization, but continues and flourishes in the receiving organization. The 
fascinating part is that it is hard to replicate as it depends on a particular setting found in the receiving organization where new knowledge is mixed with the existing one to create the unique combination leading to competitive advantage.

The marketing of research, although a quite clear term, is another concept associated with technological transfer, with which the latter is often confused. The marketing of research is represented by the process of developing new ideas or research results transformed into products or services launched on the market (Samtani, 2010). To this definition we could add the idea that the marketing of research refers not only to results embedded in products or services launched on the market but also to ideas that contribute to the development of other ideas. We are talking about the fact that the technological transfer can be used to sell innovative ideas that meet the needs of each company, the process being adaptable and not universal, without the form of a standard recipe. Although the commercialization of research and technological transfer are often used with interchangeable meanings, we want to emphasize that there are many differences between them, including: the commercialization of research involves the conversion of research results into scientific innovation and later into products or services that are marketable (Harman \& Harman, 2004 cited in Samtani, 2010); authors like Thore (Samtani, 2010) explain that technological transfer allows the receiver to make their own changes to the information received until they are materialized in products or services launched on the market.

There are three components of marketing of research as: technical aspects, business aspects, and production factors. Agents facilitating technological transfer play a key role in this process and often come from academia. A vital role is played by intellectual property issues, which are part of business aspects of marketing the research. The emphasis is placed on the fact that researchers need to pay more attention to the processes by which they can protect the results of their work long before the research commences. The process of marketing research has as main players universities and business companies. Although these two categories have different styles and emphasize different things (universities want to increase their contribution to the level of knowledge, and the business environment has a more practical approach), collaboration is vital and successful in most cases.

Turning to the technological transfer term, we emphasize that although there are some notable resemblance to the concept of marketing research, the two should not be confused because the technology transfer includes a wider range of activities and processes. Technological transfer can take various forms: from licenses, foreign direct investments, technical agreements, strategic alliances (joint venture), turnkey projects, procurement of equipment (Wei, 1995 cited in Samtani, 2010 , p. 19). Other authors include in technological transfer the start-up mechanisms, licensing, work sessions, publications, and $\mathrm{R} \& \mathrm{D}$ agreements (Goptepe 2004 cited in Samtani, 2010). Beyond that, it is obvious that the technological transfer has a significantly larger scope than the commercialization of research. 
A recent study highlights the concept of marketing knowledge in strategic alliances (Kavusan, Noorderhaven, \& Duysters, 2016) when business partners choose to improve their business opportunities and enhance their competitive advantage by acquiring technological knowledge from partners. Beyond the obvious benefits, such as access to markets and new capabilities, strategic alliances are an excellent source of technological knowledge.

Entrepreneurship is another term associated with technological transfer in the context of discussing the link between innovation, entrepreneurship and technological change. Entrepreneurship is defined as the identification of an opportunity and the ability to put it in practice (Link, Siegel, \& Wright, 2015). Technological change is a term used primarily in analysing the historical evolution of technology rather than in relation to the current meaning of technological transfer. Technological entrepreneurship can be achieved through the education of young graduates so that they can develop innovative ideas and create new businesses that add value, improve life and discover new technological results (Momete, 2016).

In older publications, the term technological transfer is often associated with the concept of diffusion, authors pointing out that the two were often interchangeable used (Stewart, 1987). The same source underlines the clear distinction between them, emphasizing that technological transfer focuses on the knowledge owner's interest in generating innovation, and diffusion/spreading is limited by the desire and the ability to adopt new knowledge (Stewart, 1987). Other authors recall the concept of diffusion of innovation, which was widely spread around 2003, when more than 5,000 papers related to this concept (Workgroup, 2011) were published in the literature. The growing popularity of this concept has led to the development of a research area called "implementation of science" as an interdisciplinary field that examines in detail the factors that facilitate the implementation of innovation and technological transfer (Workgroup, 2011).

Technological learning implies knowledge transfer, which is another term confused with technology transfer as the two concepts are often used with interchangeable meaning. Simonin explains that knowledge transfer always becomes a technology transfer and gives the example of multinationals which transfer know-how in strategic alliances (Simonin in Wahab et al., 2012). Knowledge transfer does not focus only on transferring knowledge, but also on the absorptive capacity of the organization. Which aligns with Bratianu's golden rule of keeping intellectual capital intellectual in organizations (Bratianu, 2018), confirming that international productivity and competitiveness of a country depend on the rapid accumulation of knowledge (Nastase \& Badea, 2015) which is also valid for companies. Furthermore, we come yet again to the idea that transferring knowledge does not imply the process is over as it is crucial to analyze how the new knowledge can be integrated in the existing one and used together.

The difference between knowledge transfer and technology transfer is explained based on their purpose. Consequently, knowledge transfer implies a broader, more inclusive construct that is directed more toward understanding the 
"whys" for change, while technology transfer is a narrower and more targeted construct that usually embodies certain tools for changing the environment (Gopalakrishnan \& Santoro, 2004)But besides the differences between them we must agree that both concepts overlap in some ways, though technology transfer is a more comprising term as it also includes innovation.

\section{The Relationship between Innovation and Technology Transfer}

Innovation is defined almost unanimously as an idea, a concept, a process regarding the projection, operationalization, experimentation of a model, a product, a process, a new functional structure with the purpose of being applied industrially (Pleşa, Ciotea, \& Naum, 1996). Moreover, innovation does not necessarily imply an absolute novelty, but so does invention. In order to define innovation Manole includes the following elements: an idea, a concept, scientific process; an industry alliance; a national or international network; strong intellectual property protection (Manolea, 2005). According to the dictionary innovation represents the action or process of innovating and its result (DEX, 1998).

Innovation is the process of getting new results, such as the launch of a new product, using new techniques, identifying new resources (Schumpeter, 1934), others say it is the process of accepting and implementing new ideas, processes, products of services (Thompson, 1965 cited in Dubickis \& Gaile-Sarkane, 2015)which energizes the process for enhancing organizational performance (Ferdinand \& Wahyuningsih, 2018). Technology transfer is the innovation vehicle, the mean through which knowledge reaches its users.

Innovation is an interesting topic, but that is not the reason why the interest in innovation is high, especially from the political decision-makers. The interest is mainly influenced by the positive effects that innovation has on the innovative product, organization, and on society (Fagerberg, Feldman, \& Srholec, 2013). According to studies conducted at the level of the European Union, companies that prioritize innovation are the ones with the highest turnover growth: $79 \%$ of the companies that have introduced at least one innovation since 2011 have registered an increase in turnover with more than $25 \%$ by 2014 (European Commission, 2018). The same study identifies difficulties in managing innovation from small and medium-sized enterprises: $63 \%$ of SMEs said they have introduced at least one innovation since 2011 compared to $85 \%$ of large companies; $71 \%$ of the SMEs that participated in the study, compared to $48 \%$ of large enterprises with more than 500 employees, faced difficulties in marketing innovation due to insufficient financial resources (European Commission, 2018). Also, there are studies showing that certain country-related factors have an impact on the level and type of innovation behavior displayed by female led-businesses (Filculescu, 2016), confirming once more the complex nature of innovation.

Knowledge, knowing and knowledge management are recognized as very important for the development of a business. It is interesting that this vast field and innovation have been theoretically approached and treated in practice as

$428 \quad$ Review of International Comparative Management Volume 19, Issue 4, October 2018 
two separate phenomena for a long time. Recently, researchers have begun to support the idea that the two fields have roots in similar processes and that they should be approached together to create a comprehensive picture of the literature (Asimakou, 2009).

Innovation is defined in the literature as an idea, a concept, a process for designing, operationalizing and experimenting a new product, process or functional structure for industrial application (Pleşa et al., 1996). Two main trends can be distinguished in innovation theory (Bessant, Phelps, \& Adams, 2005): the first addresses innovation as a rational planning process and the second as a social and political aspect that influences organizational culture (Fonseca, 2002). Innovation is the tool or mean used by entrepreneurs for exploiting change as an opportunity for a different, improved business or for another service (Alum Jr, 1986).

Regarding the sources of innovation, it is commonly mentioned in literature Drucker's opinion (Alum Jr, 1986) that there are seven sources of innovation that can come from both the internal and the external environment of the organization: the unexpected, the disagreement determined by different ideas, the need caused by the process, changes in industry and market, demographic changes, changes of perception and new knowledge. Although customers are often the ones that determine innovation, it can also be influenced by changes in the organization, at the level of collaborators or even competitors.

Technological transfer is a process by which a knowledge system (patented or non-patented) is transferred to different organizations capable of materializing this knowledge for their own benefit or the benefit of society in general. Technology is a system of scientific and technical knowledge regarding processes, procedures and work schedules materialized in equipment and/or documentation and know-how used to design, manufacture, operate, support and eventually market a product or category of products, or for accomplishing an activity or category of activities.

Technological transfer is approached as a sub-process of innovation or as a follow-up phase, necessary for the continuation and completion of the innovation (Manolea, 2005). Thus, the process with a high level of creativity specific to the development of technology is followed by innovation. Technological transfer is the mechanism that supports the implementation, acceptance and use of new technologies in the market. Both processes, innovation and technological transfer are complex, as they usually involve more organizations that need to collaborate efficiently, even though there may be different perspectives on important issues. Three innovation and technological transfer (TT) roles can be introduced to prevent potential problems: Technology Provider, Technology Receiver and Technology Transfer Facilitator. An organization can perform several roles in the process of innovation and technological transfer, and a role can also be assigned to several organizations (Mitasiunas, 2013). Innovation is huge source of success, which leads to growth, sustainability in the business world today.

Technological transfer is often perceived as a component part of innovation, a sub process, which comes to support the exploitation of the obtained 
results. Innovation is reached, and it is transmitted to the economic agents through a process of technological transfer.

In the literature two basic components of innovation are described, discussed when describing the link between innovation and technological transfer. These two components include: (1) knowledge and its conversion in new products and services to meet consumer needs; (2) inventions and their successful implementation. Inventions are most often made in universities and then transferred to organizations from the business environment. Through technology transfer, inventions are transformed into innovations through the use of appropriate marketing methods and their successful implementation. All this transformation process is accomplished through technology transfer (FLC, 2006).

The relationship between technological transfer and innovation translates as follows: unlike technological transfer, innovation is a much wider process, including besides specific organizational aspects, social issues (social innovation), aspects regarding public interest organizations (agencies, various forms of state owned organization), innovation for inclusive development, respectively innovation made by users of products and services produced by organizations (Iizuka, 2013). Innovation tends not only to provide solutions to increase the productivity of an enterprise but to solve the problems of the entire community, including business problems.

Some authors mention technological novelty, trying to delineate it from the innovative invention. It is considered that new technologies are being developed and technological changes are taking place when new technological functionalities are introduced into the existing technological repertoire, and the innovative invention refers to new artefacts, devices, processes, materials or compounds - may not necessarily involve technological novelty (Strumsky \& Lobo, 2015). There is no consensus on the definition of technological novelty and no measuring system covering different levels of innovative inventions, but Strumsky and Lobo have built based on their study a taxonomy with four major categories (2015): original creations, innovative combinations, combinations, refining.

Innovation involves more than a new idea or a new technology. To be able to talk about innovation, the introduction of new technology on the market, namely the application of the invention, must be approached. The development of new technologies can be achieved at the organization level, within specialized departments or at the level of organizations specialized in research and development. 
Table 1. Innovation and TT Specific Roles

\begin{tabular}{|c|c|c|c|}
\hline $\begin{array}{c}\text { Roles in } \\
\text { innovation } \\
\text { and TT } \\
\end{array}$ & Description of the role & $\begin{array}{l}\text { Specific } \\
\text { process }\end{array}$ & Role-specific activities \\
\hline $\begin{array}{c}\text { Technology } \\
\text { provider }\end{array}$ & $\begin{array}{l}\text { Technology providers focus on } \\
\text { technology development. } \\
\text { Usually the role is performed } \\
\text { by universities or research } \\
\text { institutes. At this level there } \\
\text { should be collaborative } \\
\text { activities. }\end{array}$ & $\begin{array}{c}\text { Technology } \\
\text { development }\end{array}$ & $\begin{array}{c}\text { basic research, } \\
\text { applied research, } \\
\text { creating an in vitro } \\
\text { prototype, } \\
\text { industrial replication. }\end{array}$ \\
\hline $\begin{array}{l}\text { Technology } \\
\text { receiver }\end{array}$ & $\begin{array}{l}\text { Technology receivers are those } \\
\text { organizations that apply new } \\
\text { technologies to improve } \\
\text { products, services, processes, } \\
\text { or the work environment. }\end{array}$ & Innovation & $\begin{array}{l}\text { maintaining awareness of } \\
\text { new technology, } \\
\text { selecting new } \\
\text { technologies, } \\
\text { preparation for infusion, } \\
\text { infusion of new } \\
\text { technologies, } \\
\text { innovation management. }\end{array}$ \\
\hline $\begin{array}{l}\text { Facilitator } \\
\text { of } \\
\text { technology } \\
\text { transfer }\end{array}$ & $\begin{array}{l}\text { The facilitator role can be } \\
\text { accomplished by any } \\
\text { organization that facilitates or } \\
\text { supports technological } \\
\text { transfer. Facilitators can be } \\
\text { perceived as a bridge between } \\
\text { technology provider and } \\
\text { technology receiver by linking } \\
\text { those who develop new } \\
\text { technologies and those who } \\
\text { need them. Collaboration } \\
\text { between universities and } \\
\text { industry can be an efficient } \\
\text { mechanism for supporting } \\
\text { innovation and technological } \\
\text { transfer. }\end{array}$ & $\begin{array}{l}\text { Technological } \\
\text { transfer }\end{array}$ & $\begin{array}{l}\text { identification of contacts, } \\
\text { identification of needs, } \\
\text { searching for adequate } \\
\text { and available } \\
\text { technologies, } \\
\text { identifying industrial } \\
\text { applications, } \\
\text { support in the preparation } \\
\text { and honouring of } \\
\text { contracts. }\end{array}$ \\
\hline
\end{tabular}

Source: (Mitasiunas, 2013)

Technological transfer is equally important in all cases and can have an important contribution to the success of the innovation process. If technological development is the most important aspect in the process of developing new technologies, economic and social success is equally important in the case of innovation, being necessary for new technologies to be profitable and accepted by customers and collaborators. Technological transfer supports the innovation process, facilitating the application of new technologies. 


\section{Conclusion}

In Figure 2 we can see seven of the main concepts with which technological transfer is associated in the literature. These are graphically highlighted in the form of petals of the same flower because they are more or less close to the significance and functionality of the technological transfer, but none of them perfectly overlaps.

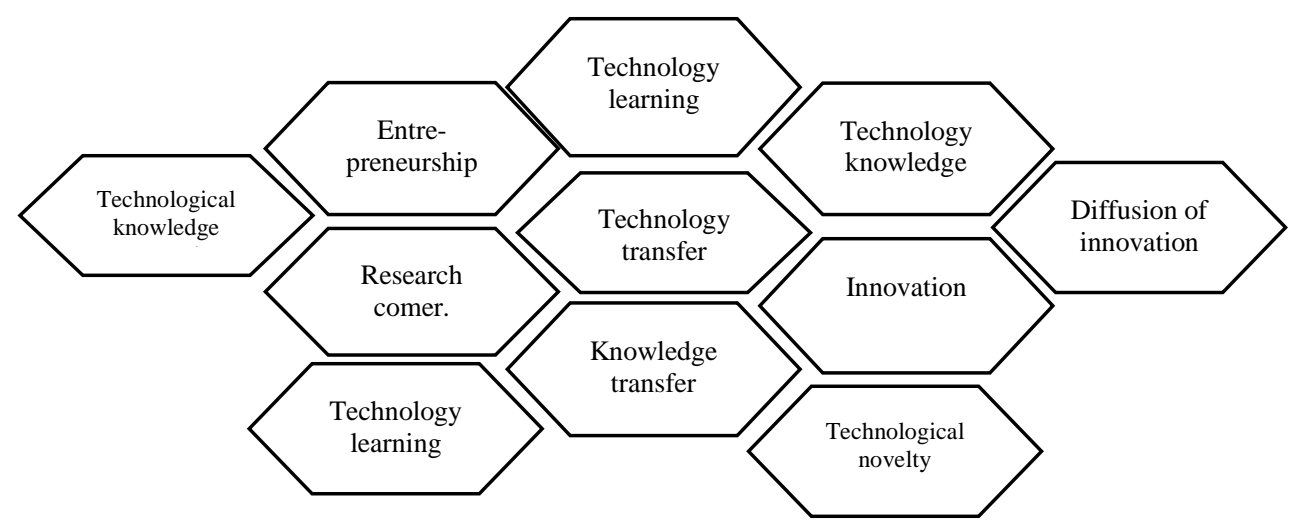

Figure 2. Core Concepts Associated with Technology Transfer

Whether we are talking about technological knowledge, the technological knowledge network, technological learning, knowledge transfer, innovation, research, entrepreneurship, technology entrepreneurship, technological change or innovation, technology diffusion, all these concepts are incomplete as a definition and degree of coverage in an attempt to replace the meaning of the technological transfer. Moreover, we would like to emphasize that they have their own value, which we do not intend to challenge, being considered related concepts in the literature, but which cannot substitute the meaning of technological transfer.

Technological transfer covers a wide range of activities and processes, ranging from optimizing a company process, applying a chemical formula to improving organizational culture, including tailor-made steps for each situation. This may explain the fact that over time there have been many concepts with which this comprehensive term has often been confused or associated. Due to this future research is needed to establish the key determinants of a successful technology transfer process in the Romanian business environment.

\section{ACKNOWLEDGEMENTS}

Partnership for the transfer of innovative technologies and advanced materials in visual arts industry (production, conservation, restoration) TeMATICArt, Project co-financed by FEDR through Competitiveness Operational Programme 2014 - 2020, Funding contract: 14/01.09.2016

432 Review of International Comparative Management Volume 19, Issue 4, October 2018 


\section{References}

Afonso, O. (2013). Diffusion and directed technological knowledge, human capital and wages. Economic Modelling, 31, 370-382.

Albors*, J., Sweeney, E., \& Hidalgo, A. (2005). Transnational technology transfer networks for SMEs. A review of the state-of-the art and an analysis of the European IRC network. Production Planning \& Control, 16(4), 413-423.

Alum Jr, R. A. (1986). Innovation and Entrepreneurship: Practice and Principles: JSTOR.

Andonova, E. (2015). Technology Transfer Management Key Factors of Success. Budapesta Conference.

Asimakou, T. (2009). Innovation, knowledge and power in organizations: Routledge.

Audretsch, D. B. (2014). From the entrepreneurial university to the university for the entrepreneurial society. The Journal of Technology Transfer, 39(3), 313321.

Autio, E., \& Laamanen, T. (1995). Measurement and evaluation of technology transfer: review of technology transfer mechanisms and indicators. International Journal of Technology Management, 10(7-8), 643-664.

Barton, J. H. (2007). New trends in technology transfer: Implications for national and international policy: International Centre for Trade and Sustainable Development (ICTSD).

Bessant, J., Phelps, B., \& Adams, R. (2005). External knowledge: A review of the literature addressing the role of external knowledge and expertise at key stages of business growth and development: Final report: Advanced Institute of Management Research.

Bratianu, C. (2018). Intellectual capital research and practice: 7 myths and one golden rule. Management \& Marketing, 13(2), 859-879.

DEX. (1998). Dicţionarul Explicativ al Limbii Române Ediţia a II-a Bucureşti: Univers Enciclopedic (pp. 853).

Dubickis, M., \& Gaile-Sarkane, E. (2015). Perspectives on Innovation and Technology Transfer. Procedia-Social and Behavioral Sciences, 213, 965970.

European Commission, E. (2018). Innovation. Retrieved 11.11.2018, from http://ec.europa.eu/growth/industry/innovation_en

Fagerberg, J., Feldman, M. P., \& Srholec, M. (2013). Technological dynamics and social capability: US states and European nations. Journal of Economic Geography, 14(2), 313-337.

Ferdinand, A. T., \& Wahyuningsih, W. (2018). Salespeople's innovativeness: a driver of sales performance. Management \& Marketing, 13(2), 966-984.

Filculescu, A. (2016). The heterogeneous landscape of innovation in female ledbusinesses-cross-country comparisons. Management \& Marketing, 11(4), 610-623. 
FLC. (2006). A Comprehensive Introduction to Technology Transfer: Federal Laboratory Consortium for Technology Transfer.

Fonseca, J. (2002). Complexity and innovation in organizations: Routledge London.

Gopalakrishnan, S., \& Santoro, M. D. (2004). Distinguishing between knowledge transfer and technology transfer activities: The role of key organizational factors. IEEE transactions on Engineering Management, 51(1), 57-69.

Iizuka, M. (2013). Innovation systems framework: still useful in the new global context? Innovation, 5.

Kavusan, K., Noorderhaven, N. G., \& Duysters, G. M. (2016). Knowledge acquisition and complementary specialization in alliances: The impact of technological overlap and alliance experience. Research Policy, 45(10), 2153-2165.

Kumar, V., Kumar, U., \& Persaud, A. (1999). Building technological capability through importing technology: the case of Indonesian manufacturing industry. The Journal of Technology Transfer, 24(1), 81-96.

Le Grange, L., \& Buys, A. J. (2002). A review of technology transfer mechanisms. South African Journal of Industrial Engineering, 13(1), 81-100.

Lin, B.-W. (2003). Technology transfer as technological learning: a source of competitive advantage for firms with limited $R \& D$ resources.

Lin, B. W. (2003). Technology transfer as technological learning: a source of competitive advantage for firms with limited $\mathrm{R} \& \mathrm{D}$ resources. $R \& D$ Management, 33(3), 327-341.

Link, A. N., Siegel, D. S., \& Wright, M. (2015). The Chicago handbook of university technology transfer and academic entrepreneurship: University of Chicago Press.

Manolea, G. (2005). Transferul tehnologic - Soluţie de valorificare a rezultatelor cercetărilor ştiinţifice Buletinul AGIR(3), 41-47.

Mitasiunas, J. (2013). Innovation and technology transfer. Bonita Project.

Momete, C., Daniela. (2016). Promoting Technological Entrepreneurship through Sustainable Engineering Education. Procedia Technology (22), 1129-1134.

Nam, Y., \& Barnett, G. A. (2011). Globalization of technology: Network analysis of global patents and trademarks. Technological Forecasting and Social Change, 78(8), 1471-1485.

Nastase, G. I., \& Badea, D. C. (2015). Innovation and Knowledge Transfer in Romanian Universities. Euromentor Journal, 6(2), 40.

Pleşa, O., Ciotea, F., \& Naum, N. (1996). Inovarea şi sfidările schimbării. Octavian Pleşa, Florin Ciotea, Nicolae Naum.

Samtani, L. A. (2010). Technology transfer evaluation in the high technology industry: an interdisciplinary perspective. Queensland University of Technology.

Schumpeter, J. A. (1934). The theory of economic development: An inquiry into profits, capital, credit, interest, and the business cycle (Vol. 55): Transaction publishers.

434 Review of International Comparative Management Volume 19, Issue 4, October 2018 
Shin, J., \& Park, Y. (2010). Evolutionary optimization of a technological knowledge network. Technovation, 30(11), 612-626.

Stewart, C. T. (1987). Technology transfer vs. diffusion: A conceptual clarification. The Journal of Technology Transfer, 12(1), 71-79.

Strumsky, D., \& Lobo, J. (2015). Identifying the sources of technological novelty in the process of invention. Research Policy, 44(8), 1445-1461.

Wahab, S. A., Rose, R. C., \& Osman, S. I. W. (2012). Defining the concepts of technology and technology transfer: A literature analysis. International business research, 5(1), 61 .

Winkelbach, A., \& Walter, A. (2015). Complex technological knowledge and value creation in science-to-industry technology transfer projects: The moderating effect of absorptive capacity. Industrial Marketing Management, 47, 98-108.

Workgroup, A. T. T. C. N. T. T. (2011). Research to practice in addiction treatment: key terms and a field-driven model of technology transfer. Journal of substance abuse treatment, 41(2), 169-178. 